\title{
INTERFERENCE INTERACTIONS OFTWO SPECIES OF Echinochloa GENUS WITH RICE
}

\author{
Hashem Aminpanah ${ }^{1 *}$, Peyman Sharifi ${ }^{1}$, and Saeed Firouzi ${ }^{1}$
}

The aim of this study was to evaluate the relative competitive ability of barnyardgrass (BYG, Echinochloa crus-galli (L.) P. Beauv.) compared to rice barnyardgrass (ECPH, E. oryzicola (Vasinger) Vasinger) against rice (Oryza sativa L.) cv. Hashemi in a replacement series study. Experiment was arranged in randomized complete block design with three replicates using a factorial treatment arrangement. Factors were two species of Echinochloa genus (BYG and ECPH) and five rice:BYG or rice:ECPH mixture proportions $(8: 0,6: 2,4: 4,2: 6$, and $0: 8)$. Relative yield total of aboveground dry weight, root dry weight and leaf area indicated that BYG or ECPH were competing for the same resources with 'Hashemi' . In general, replacement series curves and relative crowding coefficient (RCC) values demonstrated that both BYG and ECPH were more competitive than 'Hashemi'. BYG had significantly higher aboveground dry weight, root dry weight, tiller number, leaf area, and plant height than ECPH, when grown with 'Hashemi'. This experiment confirmed that BYG was more competitive than ECPH against 'Hashemi'.

Key words: Echinochloa crus-galli, competitiveness, interference, Oryza sativa, Echinochloa oryzicola.

$\mathrm{R}$ ice (Oryza sativa L.) is a staple food for nearly one-half of the world's population. Weeds are one of the major constraints in rice production. One estimate at International Rice Research Institute (IRRI) suggested weed growth in weed-free plots reduced yield as much as 34\% in transplanted rice (De Datta, 1991). Michael (1983) reported about 50 species of Echinochloa genus listed worldwide, and most are important, especially in rice fields, causing serious competition with high yield reduction. Two important species of Echinochloa genus in rice paddy field of Iran are barnyardgrass (E. crusgalli (L.) P. Beauv.) and rice barnyardgrass (E. oryzicola (Vasinger) Vasinger (=Echinochloa phyllopogon (Stapf) Stapf ex Kossenko). Barnyardgrass is hexaploid, $2 n=$ $6 \mathrm{X}=54$ (Carretero, 1981). Barnyardgrass is a persistent annual grass that reproduces each year from seed stock deposited in previous summer and fall seasons (Holm et al., 1979). Season-long competition from E. crus-galli reduced rice yields by $38 \%$ to $64 \%$ depending on the rice cultivar (Smith, 1988; Stauber et al., 1991). Echinochloa oryzicola is tetraploid, $2 n=4 \mathrm{X}=34$ (Carretero, 1981), and almost exclusively grows as rice weeds. Yabuno (1966) reported that E. oryzicola is the most dominant and persistent weed in flooded rice of Japan. Yaghoubi et al. (2006) reported that $40 \mathrm{BYG}$ and ECPH plants $\mathrm{m}^{-2}$ reduced rice grain yield as much as 60 and $65 \%$, respectively.

${ }^{1}$ Department of Agronomy and Plant Breeding, Rasht Branch, Islamic Azad University, Rasht, Iran.

"Corresponding author (aminpanah@iaurasht.ac.ir).

Received: 14 October 2011.

Accepted: 26 June 2012.
Crops and weeds compete for the same resources, nutrients, water, space, and light. Competition begins when crops and weeds grow in close proximity and the supply of any necessary growth factor falls below the demand of both. The overall effect of crop-weed competition is a reduction in the biomass of rice and a reduction in grain yield. Plant density and proportion of one species to another are key factors in plant competition (Harper, 1977). Harper (1977) intensively used the replacement series model to measure the aggressiveness of a species. Radosevich (1987) suggested that replacement method is most valuable for assessing the competitive effects of two species at a single total density and determining the relative effects of interferences within and between species.

It has been reported that the dominant species of Echinochloa genus in rice paddy field of Iran is changing from E. crus-galli to E. oryzicola (Yaghoubi et al., 2006) that has either mimicry or photoperiodic sensitivity synchronizing to that of rice (Yamasue, 2001). A lack of data exists concerning the competitive ability of ECPH compared to BYG against rice cultivars. Therefore, the aim of this study was to evaluate the relative competitiveness of ECPH compared to $\mathrm{BYG}$ against a native rice cv. Hashemi, which is intensively cultivated in north of Iran, in a replacement series study.

\section{MATERIALS AND METHODS}

\section{Competition indices}

The four models for interference, proposed by Harper 
(1977) and adapted by Fleming et al. (1988), were used to evaluate the competitiveness of either BYG or ECPH against rice 'Hashemi'. These models described the possible outcomes of the interaction of two species when grown in a replacement series (Radosevich, 1987; Oberg et al., 1996). Replacement series diagrams were constructed for the response of aboveground dry weight, root dry weight, leaf area and tiller number to species proportion. The following indices were used in the present experiment.

\section{The relative yield total (RYT)}

Relative yield (RY) and relative yield total (RYT) for aboveground dry weight, root dry weight, leaf area and tiller number were calculated according to the following equations (Harper, 1977):

$$
\mathrm{RY}_{\mathrm{r}}=(\mathrm{Yrb} / \mathrm{Yrr}) \text { or } \mathrm{RY}_{\mathrm{b}}=(\mathrm{Ybr} / \mathrm{Ybb})
$$

where $\mathrm{Yrb}$ or $(\mathrm{Ybr})=$ yield per pot of rice or (weed) when grown with weed (or rice) and Yrr or $(Y b b)=$ yield per pot of rice (weed) in monoculture.

$$
\mathrm{RYT}=\mathrm{RY}_{\mathrm{r}}+\mathrm{RY}_{\mathrm{b}}
$$

Harper (1977) advocated that RYT can be used to describe the mutual relationships of pairs of species that may or may not be making demands on the same resources in the environment. In two species mixtures, an RYT value close to 1.00 indicates that the two species make equal demands on the same limiting resources. RYT values greater than 1.00 indicate that species that still compete for the same resources may also make demands on different resources. RYT values less than 1.00 indicate mutual antagonism (Bi and Turvey, 1994).

\section{The relative crowding coefficient $(\mathrm{RCC})$}

Relative crowding coefficient (RCC), a measure of the relative dominance of one species over the other in a mixture, was calculated following Novak et al. (1993) as follows:

$$
\mathrm{RCC}=(((\mathrm{Wr} 75: 25 / \mathrm{Wb} 75: 25)+(\mathrm{Wr} 50: 50 / \mathrm{Wb} 50: 50)
$$$$
+(\mathrm{Wr} 25: 75 / \mathrm{Wb} 25: 75)) / 3) /(\mathrm{Wr} 100: 0 / \mathrm{Wb} 100: 0)
$$

where $\mathrm{Wr} n: n$ is aboveground or root dry weight, leaf area and tiller number of rice at a ratio of n:n and Wbn:n is aboveground or root dry weight, leaf area and tiller number of BYG or ECPH at a ratio of n:n. The larger the RCC value, the greater the competitiveness with the other species. RCC values of approximately 1 indicate that the two species are equal competitors and values $>1$ or $<1$ indicate that a species is more or less competitive, respectively, than another species.

\section{Experimental design, plant culture and management}

A pot experiment was conducted at Rice Research Station in Tonekabon (36 $54^{\prime} \mathrm{N}, 40^{\circ} 50^{\prime} \mathrm{E}$; $20 \mathrm{~m}$ a.s.1.), north of Iran, from June to September of 2010. The experiment was conducted as a randomized complete block design with a factorial treatment arrangement and three replicates. Factors were two species of Echinochloa genus (E.crus- galli and E. oryzicola) and five rice:BYG or rice: $\mathrm{ECPH}$ ratios $(8: 0,6: 2,4: 4,2: 6$, and $0: 8)$. Actual plant numbers per pot for each mixture were 8:0, 6:2, 4:4, 2:6, and 0:8, respectively. Pots $(35 \mathrm{~cm}$ average diameter by $30 \mathrm{~cm}$ deep) were arranged in a rectangular grid pattern with approximately $40 \mathrm{~cm}$ between edges of adjacent pots. Pots were filled to a depth of $25 \mathrm{~cm}$ with clay loam soil from the Tonekabon Rice Research station farm. Soil properties were $2.2 \%$ organic matter content, $37 \%$ clay, $44 \%$ silt, $19 \%$ sand, $6.8 \mathrm{pH}, 29.9$ cation exchange capacity (CEC) (meq $100 \mathrm{~g}$ ). Rice seeds were sown in the nursery on 1 April 2010. According to rice:BYG or rice:ECPH ratio in each pot, three 'Hashemi' seedlings or one germinated BYG or ECPH seed were transplanted (or planted) in hills with a square arrangement, with hills equidistant from the sides of the pot and from each other, on 1 June 2010. Total fertilizer applied was $100 \mathrm{~kg} \mathrm{~N} \mathrm{ha}{ }^{-1}, 75 \mathrm{~kg} \mathrm{P}$ $\mathrm{ha}^{-1}$, and $150 \mathrm{~kg} \mathrm{~K} \mathrm{ha}^{-1}$ with split application broadcast at transplanting stage ( $30 \% \mathrm{~N}$ and $100 \% \mathrm{PK})$, at panicle initiation $(35 \% \mathrm{~N})$, and $5 \mathrm{~d}$ before flowering $(35 \% \mathrm{~N})$. Consistent with the lowland paddy field practices in north of Iran, a permanent flood water level was maintained at $10 \mathrm{~cm}$ from approximately $7 \mathrm{~d}$ after transplanting until 20 $\mathrm{d}$ before harvesting stage. Moreover, during the growing season, all unwanted weeds except the planted BYG or ECPH were hand weeded.

\section{Plant sampling}

At maturity stage, plant height (from the soil surface to the top of the plant canopy) was measured. Plants were harvested by hand-cutting at soil surface and subsequently aboveground biomass of rice, BYG, and ECPH were separated, and tillers of each species were counted. Leaf area was measured with a leaf area meter (LI-3000A, LI-COR, Lincoln, Nebraska, USA). Roots of rice, BYG, and ECPH were washed gently and thoroughly to remove soil particles so that the root tissues remained intact and subsequently were separated. Rice, BYG and ECPH aboveground and belowground (root) biomass from each pot was placed in separate paper bags, dried at $72{ }^{\circ} \mathrm{C}$ for $96 \mathrm{~h}$, and weighted. From the yield data, relative crowding coefficients of the species towards each other and RYT of each species combination were computed.

\section{Statistical analyses}

Data were subjected to ANOVA and means were separated using Fisher's Protected LSD at the 0.05 level. All statistical analyses were conducted by using SAS (SAS Institute, 2002). To determine whether RYT differed significantly from 1.0 or not, the following equation was used (Gealy et al., 2005):

Cutoff $=1 \pm\left(t^{*} \times\right.$ standard error of the mean $)$ where $t^{*}=$ the two-sided critical value from the t-table with degree of freedom (df) equal to $\mathrm{df}$ associated with the term used as the error term in the F-test. 


\section{RESULTS AND DISCUSSION}

\section{Aboveground dry weight}

Aboveground dry weight $\left(\mathrm{g} \mathrm{plant}^{-1}\right)$ of 'Hashemi' reduced significantly when rice:BYG or rice:ECPH mixture proportion decreased. The highest aboveground dry weight for 'Hashemi' was obtained when grown alone. This indicates that 'Hashemi' grew better with intraspecific than with interspecific competition. Moreover, aboveground dry weight of 'Hashemi' when grown with BYG was usually less than that when grown with ECPH, specially in 6:2 rice:weed mixture proportion (Table 1). On the other hand, aboveground dry weight of both BYG and $\mathrm{ECPH}$ increased significantly when rice:weed mixture proportion decreased, but BYG, when grown at different mixture proportions, had greater aboveground dry weight than ECPH (Table 2). This result indicates that BYG or ECPH was more competitive than 'Hashemi' and gains resources at the expense of the rice cultivar. Moreover, this result suggests that BYG was a superior competitor to ECPH. Fleming et al. (1988) reported that the more aggressive species in a mixture increased in weight with increased proportions of the less aggressive species.

Replacement series diagrams for relative shoot dry weight illustrated the competition between 'Hashemi' and $\mathrm{BYG}$ or ECPH. As shown in the Figure 1, the intersection

Table 1. Aboveground dry weight (ADW), root dry weight (RDW), tiller number (TN), leaf area (LA) and height (H) of 'Hashemi' rice as influenced by 8:0, 6:2, 4:4 and 2:6 rice:weed mixture proportions.

\begin{tabular}{lccccccc}
\hline $\begin{array}{l}\text { Rice } \\
\text { cultivar }\end{array}$ & $\begin{array}{c}\text { Weed } \\
\text { species }\end{array}$ & $\begin{array}{c}\text { Rice: } \\
\text { weed } \\
\text { ratios }\end{array}$ & ADW & RDW & \multicolumn{1}{c}{ TN } & LA & H \\
\hline \multirow{3}{*}{ Hashemi } & BYG & $8: 0$ & $24.83 \mathrm{a}$ & $5.54 \mathrm{c}$ & $15.91 \mathrm{a}$ & $881 \mathrm{ab}$ & $64.50 \mathrm{a}$ \\
& & $6: 2$ & $20.80 \mathrm{~b}$ & $5.46 \mathrm{c}$ & $13.37 \mathrm{c}$ & $579 \mathrm{~d}$ & $57.90 \mathrm{c}$ \\
& & $4: 4$ & $20.20 \mathrm{~b}$ & $5.75 \mathrm{c}$ & $10.63 \mathrm{e}$ & $557 \mathrm{~d}$ & $51.30 \mathrm{e}$ \\
& & $2: 6$ & $14.54 \mathrm{~d}$ & $7.56 \mathrm{ab}$ & $8.07 \mathrm{f}$ & $590 \mathrm{dc}$ & $46.04 \mathrm{f}$ \\
Hashemi & ECPH & $8: 0$ & $24.83 \mathrm{a}$ & $5.54 \mathrm{c}$ & $15.91 \mathrm{a}$ & $881 \mathrm{ab}$ & $64.50 \mathrm{a}$ \\
& & $6: 2$ & $20.50 \mathrm{~b}$ & $6.51 \mathrm{bc}$ & $14.72 \mathrm{~b}$ & $613 \mathrm{dc}$ & $61.90 \mathrm{~b}$ \\
& & $4: 4$ & $19.98 \mathrm{~b}$ & $6.74 \mathrm{bc}$ & $12.00 \mathrm{~d}$ & $661 \mathrm{dc}$ & $55.30 \mathrm{~d}$ \\
& & $2: 6$ & $17.36 \mathrm{c}$ & $9.07 \mathrm{a}$ & $10.20 \mathrm{e}$ & $1065 \mathrm{a}$ & $50.00 \mathrm{e}$ \\
LSD (0.05) & - & 2.81 & 1.27 & 1.01 & 217 & 2.5
\end{tabular}

BYG: Barnyardgrass; ECPH: rice barnyardgrass.

Table 2. Aboveground dry weight (ADW), root dry weight (RDW), tiller number (TN), leaf area (LA) and height (H) of barnyard grass (BYG) and rice barnyardgrass (ECPH) as influenced by $8: 0,6: 2,4: 4$ and 2:6 weed:rice mixture proportions.

\begin{tabular}{lcccccc}
\hline $\begin{array}{l}\text { Weed } \\
\text { species }\end{array}$ & $\begin{array}{l}\text { Rice: } \\
\text { weed } \\
\text { ratios }\end{array}$ & \multicolumn{7}{c}{ ADW } & RDW & \multicolumn{1}{c}{ TN } & LA & H \\
\hline \multirow{6}{*}{ BYG } & $8: 0$ & $38.28 \mathrm{c}$ & $7.30 \mathrm{de}$ & $15.2 \mathrm{ab}$ & $2183 \mathrm{~d}$ & $92.79 \mathrm{a}$ \\
& $6: 2$ & $41.82 \mathrm{bc}$ & $7.71 \mathrm{~d}$ & $15.9 \mathrm{a}$ & $2632 \mathrm{c}$ & $89.77 \mathrm{~b}$ \\
& $4: 4$ & $44.30 \mathrm{~b}$ & $8.93 \mathrm{c}$ & $14.93 \mathrm{ab}$ & $3290 \mathrm{~b}$ & $77.83 \mathrm{~d}$ \\
& $2: 6$ & $58.09 \mathrm{a}$ & $15.90 \mathrm{a}$ & $13.13 \mathrm{~d}$ & $4622 \mathrm{a}$ & $60.72 \mathrm{f}$ \\
ECPH & $8: 0$ & $30.15 \mathrm{de}$ & $5.54 \mathrm{f}$ & $15.6 \mathrm{a}$ & $1691 \mathrm{e}$ & $83.44 \mathrm{c}$ \\
& $6: 2$ & $28.03 \mathrm{e}$ & $6.51 \mathrm{e}$ & $14.33 \mathrm{bc}$ & $1718 \mathrm{e}$ & $79.40 \mathrm{~d}$ \\
& $4: 4$ & $33.74 \mathrm{~d}$ & $6.57 \mathrm{e}$ & $13.19 \mathrm{dc}$ & $2466 \mathrm{~cd}$ & $71.61 \mathrm{e}$ \\
& $2: 6$ & $43.83 \mathrm{~b}$ & $11.66 \mathrm{~b}$ & $11.56 \mathrm{e}$ & $3098 \mathrm{~b}$ & $60.64 \mathrm{f}$ \\
LSD (0.05) & - & 3.84 & 0.89 & 1.14 & 400 & 3.00 \\
\hline
\end{tabular}

BYG: Barnyardgrass; ECPH: rice barnyardgrass.
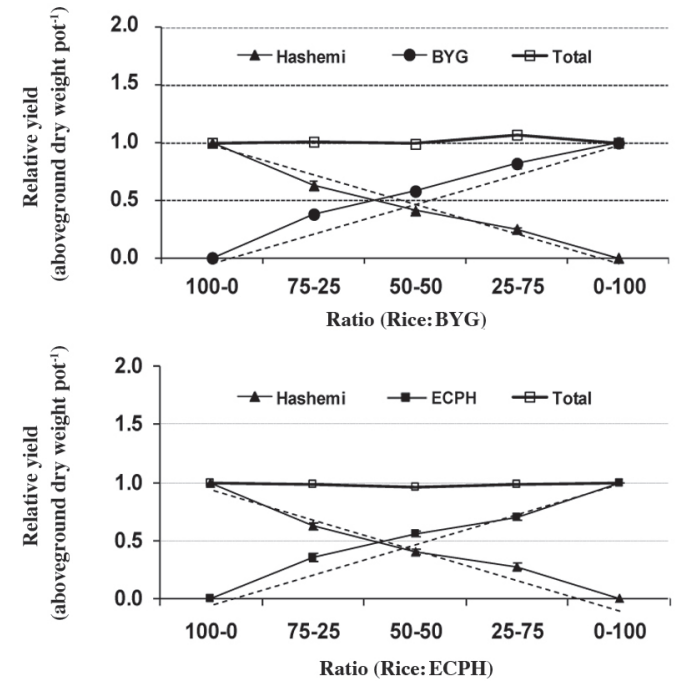

The two straight dashed lines in each frame indicate the theoretically expected responses for two equally competitive species, which intersect at the point of equivalency (Harper, 1977).

Figure 1. Relative aboveground dry weights of 'Hashemi' rice $(\Delta)$,

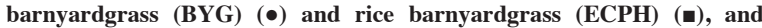
relative yield totals (RYT) ( $\square$ ) as influenced by rice:weed mixture proportions in a replacement series.

of the 'Hashemi' curve with that of either BYG or ECPH was to the left of the 50:50 mixture proportions (point of equivalency of the expected yield). This indicates that BYG or ECPH was more competitive than 'Hashemi'. The RYTs ranged from 0.96 to 1.07 , but all were not significantly different from 1 , on the basis of the cutoff of not $>1.10$ or $<0.90$. This indicates that 'Hashemi' and BYG or ECPH were competing for the same resources. This result was in agreement with some previous studies (Estorninos et al., 2002; Gealy et al., 2005).

The RCC was used to measure the competitiveness of one species upon another (Table 3). The greater RCC of $\mathrm{BYG}$ or ECPH over 'Hashemi' indicates and also confirms the results of RY for aboveground dry weight that both BYG and ECPH was superior competitor to 'Hashemi'. Moreover, the greater RCC of BYG over ECPH indicates the aggressiveness of BYG against ECPH in aboveground dry weights (Table 3). Fischer et al. (2000) reported that when competing for limited resources, the species with the greater RCC in the mixture is the stronger competitor.

Table 3. Mean comparison for the effect of rice cultivar and species of Echinochloa genus (BYG or ECPH) on relative crowding coefficient (RCC) for aboveground dry weight (ADW), root dry weight (RDW), tiller number (TN), leaf area (LA) and height $(H)$.

\begin{tabular}{lccccc}
\hline & \multicolumn{5}{c}{ Relative crowding coefficient (RCC) } \\
\cline { 2 - 6 } $\begin{array}{l}\text { Species in } \\
\text { mixture }\end{array}$ & ADW & RDW & TN & LA & H \\
\hline BYG & $1.41 \mathrm{a}$ & $1.28 \mathrm{a}$ & $1.12 \mathrm{a}$ & $2.45 \mathrm{a}$ & $1.05 \mathrm{a}$ \\
Cv. Hashemi & $0.71 \mathrm{~d}$ & $0.80 \mathrm{c}$ & $0.90 \mathrm{a}$ & $0.42 \mathrm{c}$ & $0.94 \mathrm{~b}$ \\
ECPH & $1.29 \mathrm{~b}$ & $1.22 \mathrm{a}$ & $1.09 \mathrm{a}$ & $1.54 \mathrm{~b}$ & $1.09 \mathrm{a}$ \\
Cv. Hashemi & $0.80 \mathrm{c}$ & $0.98 \mathrm{~b}$ & $0.92 \mathrm{a}$ & $0.70 \mathrm{c}$ & $0.91 \mathrm{~b}$ \\
LSD $(0.05)$ & 0.08 & 0.08 & 0.26 & 0.47 & 0.06 \\
\hline
\end{tabular}

BYG: Barnyardgrass; ECPH: rice barnyardgrass. 
Gealy et al. (2005) reported that rice cv. Lemont had lower RCC than BYG, while PI 312777 had similar RCC with BYG. Some researchers reported that differences in weed competitiveness exist between and within crops (Garrity et al., 1992; Fischer et al., 1997; Johnson et al., 1998; Fofana and Rouber, 2000; Ni et al., 2000; Fischer et al., 2001; Gealy et al., 2003; Anwar et al., 2010) and weeds species (Fleming et al., 1988; Vangessel and Karen, 1990).

\section{Root dry weight}

Root dry weight of 'Hashemi' increased dramatically at 2:6 rice:weed mixture proportion, but it did not vary statistically in the other mixture proportions (Table1). Maximum and minimum root dry weight for 'Hashemi' was recorded in 2:6 and 8:0 rice:weed mixture proportion, respectively. On the other hand, root dry weight $\left(\mathrm{g} \mathrm{plant}^{-1}\right)$ of BYG or ECPH significantly increased as weed:rice mixture proportions increased (Table 2).

The competitiveness of each species of Echinochloa genus against 'Hashemi' on the basis of the relative root dry weight was evaluated using a replacement series diagram (Figure 2). As shown in the Figure 2, the lines for 'Hashemi' and BYG intersect at the left of the point of equivalency. In other words, the curve representing 'Hashemi' was concave and the curve for BYG was convex. This indicates that BYG was more competitive than 'Hashemi' and gains resources at the expense of the cultivar. On the other hand, the lines for ECPH and 'Hashemi' intersect at the point of equivalency of the expected yield, indicating equal competitive ability between 'Hashemi' and ECPH based on root biomass
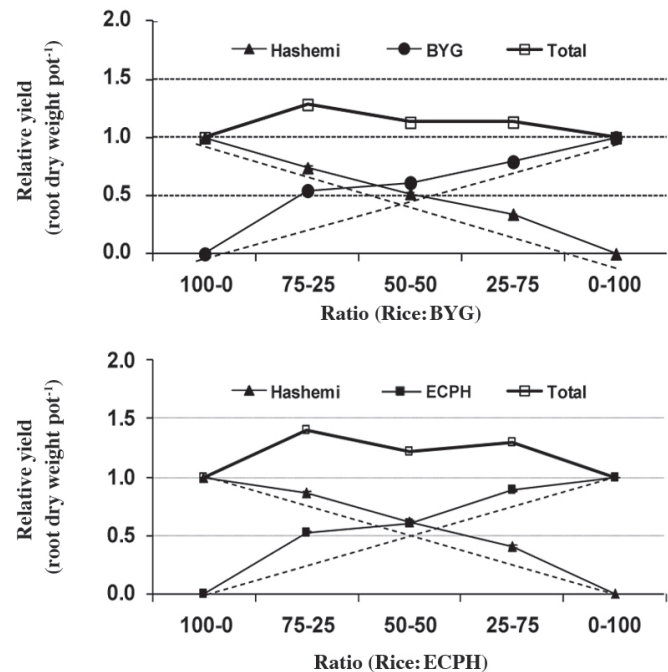

The two straight dashed lines in each frame indicate the theoretically expected responses for two equally competitive species, which intersect at the point of equivalency (Harper, 1977).

Figure 2. Relative root dry weights of 'Hashemi' rice $(\Delta)$, barnyard grass (BYG) $(\bullet)$ and rice barnyardgrass (ECPH) (๘), and relative yield totals (RYT) ( $\square$ ) as influenced by rice:weed mixture proportions in a replacement series. production. The RYTs for root dry weight of each species of Echinochloa genus and 'Hashemi' ranged from 1.13 to 1.39. In most cases, they were significantly higher than cutoff value $(<1.14$ or $>0.86)$. This response probably occurred primarily because of the reduced interference in mixtures in relation to the monocultures due to the differences in paths of resource acquisition by $\mathrm{C}_{3}$ rice plants and $\mathrm{C}_{4} \mathrm{BYG}$ or ECPH plants, respectively (Fischer et al., 2000).

The greater RCC of BYG or ECPH over 'Hashemi' indicates and also confirms the results of RY for root dry weight that both BYG and ECPH was superior competitor to 'Hashemi'. On the other hand, the RCC value for root dry weight did not significantly differ between BYG and ECPH (Table 3). This indicates similar competitive ability between them.

\section{Tiller number}

Tiller number of 'Hashemi' reduced significantly when rice: $\mathrm{BYG}$ or rice:ECPH mixture proportion decreased (Table 1). Also, 'Hashemi' had higher tiller density when planted as monoculture than when grown at the different rice:weed mixture proportions. Moreover, Tiller density of 'Hashemi' when grown with BYG was usually less than that when grown with ECPH (Table 1). These results indicate that 'Hashemi' grew better with intraspecific than with interspecific competition. On the other hand, tiller numbers of ECPH were significantly reduced as ECPH:rice ratio decreased, but tiller density of BYG was significantly decreased only at 2:6 BYG:rice mixture proportion (Table 2).

Replacement series diagrams based on relative tiller production illustrated the competitive effects between 'Hashemi' and BYG or ECPH (Figure 3). As shown in the Figure 3, two species of Echinochloa genus and Hashemi lines intersect almost at the 50:50 rice:weed mixture proportions. This result suggested that the weeds were as competitive as 'Hashemi' in tiller production. The RYTs for tiller number of BYG or ECPH and 'Hashemi' (ranging from 0.75 to 0.85 ) were lower than the cutoff values (0.94-1.06). Harper (1977) suggested that RYT value $<1$ imply mutual antagonism.

The RCC value for tiller number did not significantly differ between BYG or ECPH and 'Hashemi' (Table 3). This indicates similar competitive ability between ECPH or BYG and 'Hashemi' and neither species were dominant in root biomass production.

\section{Leaf area}

Leaf area $\left(\mathrm{cm}^{2}\right.$ plant $\left.{ }^{-1}\right)$ of 'Hashemi' decreased as rice:BYG mixture proportions decreased (Table 1). On the other hand, leaf area $\left(\mathrm{cm}^{2}\right.$ plant $\left.^{-1}\right)$ of 'Hashemi' significantly decreased at $6: 2$ and $4: 4$ rice:ECPH mixture proportions, but dramatically increased at 2:6 rice:ECPH mixture proportions. Moreover, leaf area of 'Hashemi' when grown with ECPH was significantly more than that 
when grown with BYG. These data indicate that BYG was more competitive than ECPH against 'Hashemi'. On the other hand, leaf area of BYG or ECPH increased as weed:rice mixture proportions decreased (Table 2). Moreover, leaf area for BYG was higher than for ECPH, planted either alone or in the mixture (Table 2). This result also confirmed that $\mathrm{ECPH}$ is less competitive than BYG against 'Hashemi'. Dingkuhn et al. (1999) and Karimmojeni et al. (2010) reported that leaf area was positively correlated with competitiveness.

As shown in the Figure 4, the intersection of the 'Hashemi' curve with that of either BYG or ECPH was to the left of the 50:50 mixture proportions (point of equivalency of the expected yield). This indicates that both BYG and ECPH were more competitive than 'Hashemi'. The RYTs for leaf area of 'Hashemi' and both species of Echinochloa genus ranged from 1.02 to 1.14 , but all were not significantly different from 1 , on the basis of the cutoff of not $>1.17$ or $<0.83$. This indicates that 'Hashemi' and BYG or ECPH were competing for the same resources. This result was in agreement with some previous studies (Estorninos et al., 2002; Gealy et al., 2005).

The greater RCC of BYG over ECPH indicates that BYG was more competitive than ECPH (Table 3). Moreover, the greater RCC of BYG or ECPH over 'Hashemi' indicates that both BYG and ECPH was superior competitor to 'Hashemi'.

\section{Plant height}

'Hashemi' height was reduced significantly when grown with either BYG or ECPH (Table 1). On the other hand,
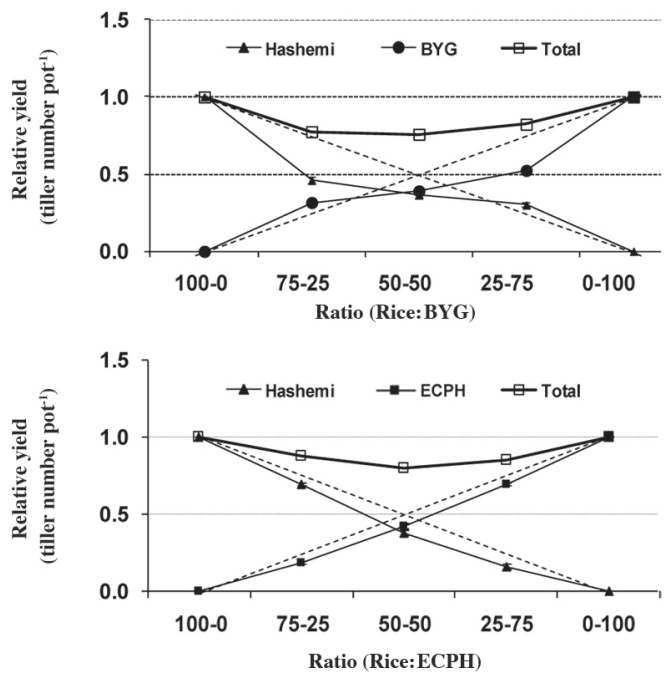

The two straight dashed lines in each frame indicate the theoretically expected responses for two equally competitive species, which intersect at the point of equivalency (Harper, 1977).

Figure 3. Relative tiller number of 'Hashemi' rice $(\Delta)$, barnyard grass

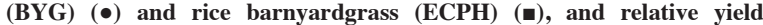
totals (RYT) ( $\square$ ) as influenced by rice:weed mixture proportions in a replacement series.
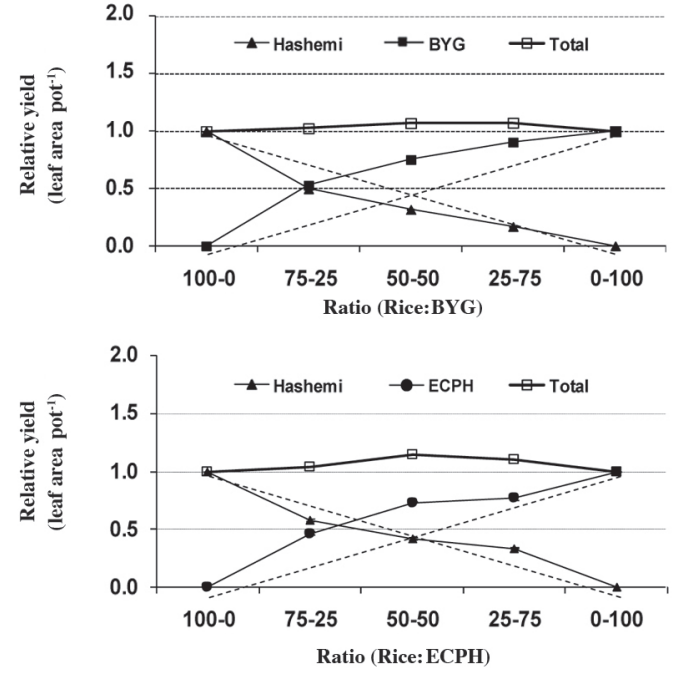

The two straight dashed lines in each frame indicate the theoretically expected responses for two equally competitive species, which intersect at the point of equivalency (Harper, 1977).

Figure 4. Relative leaf area of 'Hashemi' rice $(\Delta)$, barnyardgrass (BYG) $(\bullet)$ and rice barnyardgrass $(\mathrm{ECPH})(\square)$, and relative yield totals (RYT) ( $\square$ ) as influenced by rice:weed mixture proportions in a replacement series.

both BYG and ECPH height were reduced when they grown with 'Hashemi' (Table 2). Moreover, both BYG and ECPH were taller when planted alone than when grown together with rice at all mixture proportions (Table 2). This indicates that both BYG and ECPH grew taller with intraspecific than with interspecific competition. Garrity et al. (1992) and Drews et al . (2009) reported that weeds reduced significantly rice plant height. Also, BYG was higher than ECPH when planted as monoculture. In this experiment, the taller echinochloa species, BYG, was more competitive than the shorter Echinochloa species, ECPH. Jennings and Herrera (1968), Garrity (1992) and Karimmojeni et al. (2010) reported that plant height can be positively associated with competitiveness, but Estorninos et al. (2002) suggested that plant height can be negatively associated with competitiveness.

There was no significant difference between the RCC of BYG and ECPH for plant height, but the greater RCC of BYG or ECPH over 'Hashemi' indicated that both BYG and ECPH was superior competitor to 'Hashemi' (Table 3).

Although in this experiment the competitive ability of the BYG was higher than that of ECPH, ECPH could be an important weed in rice paddy fields because: (i) $\mathrm{EPCH}$ seeds germinate and seedlings emerge very well under anaerobic conditions. (ii) ECPH has seemingly perfect mimicry of the rice plants throughout its development from seedling to heading. This helps the weed to escape manual weeding before rice heading. The weed starts heading coincidentally with the rice plants at the period when the growers are reluctant to walk in the rice paddy to weed because it may disturb crop growth and fertilization. When weeding is begun after heading of the rice plants, 
the weed has already started shattering seeds (Yamasue, 2001)

\section{CONCLUSIONS}

The results of this experiment indicated that both Echinochloa crus-galli (BYG) and Echinochloa oryzicola (ECPH) were competing for the same resources with 'Hashemi'. In general, replacement series curves and relative crowding coefficient values indicated that BYG or ECPH was more competitive than 'Hashemi'. BYG had significantly higher aboveground dry weight, root dry weight, tiller number, leaf area, and plant height than ECPH, when grown with Hashemi. Moreover, this experiment demonstrated that BYG was superior competitor to ECPH.

Interacciones de interferencia entre dos especies del género Echinochloa con arroz. El objetivo de este estudio fue evaluar la capacidad competitiva relativa de Echinochloa crus-galli (L.) P. Beauv. (BYG) en comparación con Echinochloa oryzicola (Vasinger) Vasinger (ECPH) contra arroz (Oryza sativa L.) cv. Hashemi en un estudio de series de reemplazo. Los experimentos fueron arreglados en diseño de bloques completos al azar con tres repeticiones con un arreglo factorial. Los factores fueron dos especies del género Echinochloa (BYG y ECPH) y cinco mezclas de arroz:BYG o arroz:ECPH (8:0, 6:2, 4:4, $2: 6$ y 0:8). El rendimiento relativo total del peso seco sobre el suelo, peso seco de raíces y área foliar indicaron que BYG y ECPH estaban compitiendo por los mismos recursos con 'Hashemi'. En general, las curvas de serie de sustitución y el coeficiente relativo de competencia (RCC) demostraron que los valores BYG y ECPH fueron más competitivos que 'Hashemi'. BYG tuvo un peso seco sobre el suelo, peso seco de raíces, número de macollos, área foliar y altura de plantas significativamente superiores que ECPH cuando se cultivan con 'Hashemi'. Este experimento confirmó que BYG fue más competitivo que ECPH contra 'Hashemi'.

Palabras clave: Echinochloa crus-galli, competencia, interferencia, Oryza sativa, Echinochloa oryzicola.

\section{LITERATURE CITED}

Anwar, M.D.P., A.S. Juraimi, A. Man, A. Puteh, A. Selamat, and M. Begum. 2010. Weed suppressive ability of rice (Oryza sativa L.) germplasm under aerobic soil conditions. Australian Journal of Crop Science 4:706-717.

Bi, H., and N.D. Turvey. 1994. Inter-specific competition between seedlings of Pinus radiata, Eucalyptus regnans and Acacia melanoxylon. Australian Journal of Botany 42:61-70.

Carretero, J.L. 1981. El género Echinochloa Beauv. en el suroeste de Europa. Anales Jardín Botánico de Madrid 38:91-108.

De Datta, S.K. 1991. Principles and practices of rice production. John Wiley and Sons, New York, USA.
Dingkuhn, M., D.E. Johnson, A. Sow, and A.Y. Audebert. 1999. Relationships between upland rice canopy characteristics and weed competitiveness. Field Crops Research 61:79-95.

Drews, S., D. Neuhoff, and U. Kopke. 2009. Weed suppression ability of three winter wheat varieties at different row spacing under organic farming conditions. Weed Research 49:526-533.

Estorninos, L.E. Jr., D.R. Gealy, and R.E. Talbert. 2002. Growth response of rice (Oryza sativa) and red rice (O. sativa) in a replacement series study. Weed Technology 16:401-406.

Fischer, A.J., C.M. Ateh, D.E. Bayer, and J.E. Hill. 2000. Herbicideresistant Echinochloa oryzoides and E. phyllopogon in California Oryza sativa fields. Weed Science 48:225-230.

Fischer, A.J., H. Ramirez, K.D. Gibson, and B.D.S. Pinheiro. 2001. Competitiveness of semidwarf upland rice cultivars against palisadegrass (Brachiaria brizantha) and signalgrass $(B$. decumbens). Agronomy Journal 93:967-973.

Fischer, A.J., H.V. Ramirez, and J. Lozano. 1997. Suppression of junglerice [Echinocloa colona (L.) Link] by irrigated rice cultivars in Latin America. Agronomy Journal 89:516-552.

Fleming, G.F., F.L. Young, and Jr. A.G. Ogg. 1988. Competitive relationships among winter wheat (Tritichum aestivum), jointed goatgrass (Aegilops cylindrica), and downy brome (Bromus tectorum). Weed Science 36:479-486.

Fofana, B., and R. Rouber. 2000. Weed suppression ability of upland rice under low-input conditions in West Africa. Weed Research 40:271-280.

Garrity, D.P., M. Movillon, and K. Moody. 1992. Differential weed suppression ability in upland rice cultivars. Agronomy Journal 84:586-591

Gealy, R.D., Jr. L.E. Estorninos, E.E. Gbur, and R.S.C. Chavez. 2005. Interference interactions of two rice cultivars and their F3 cross with barnyardgrass (Echinochloa crus-galli) in a replacement series study. Weed Science 53:323-330.

Gealy, R.D., E.J. Wailes, E. Leopoldo, L.E. Estorninos Jr., and R.S.C. Chavez. 2003. Rice cultivar differences in suppression of barnyardgrass (Echinochloa crus-galli) and economics of reduced propanil rates. Weed Science 51:601-609.

Harper, J.L. 1977. Substitutive experiments. In Population biology of plants. p. 255-267. Academic Press, New York, USA.

Holm, L.G., J.V. Pancho, J.P. Herberger, and D.L. Plucknett. 1979. A geographical atlas of world weeds. John Wiley, New York, USA.

Jennings, P.R., and R.M. Herrera. 1968. Studies on competition in rice. II. Competition in segregating populations. Evolution 22:332-336.

Johnson, D.E., M. Dingkuhn, M.P. Jones, and M.C. Mahamane. 1998. The influence of rice plant type on the effect of weed competition on Oryza sativa and Oryza glaberrima. Weed Research 38:207216.

Karimmojeni, H., H.R. Mashhadi, S. Shahbazi, A. Taab, and H. Alizadeh. 2010. Competitive interaction between maize, Xanthium Strumarium and Datura Stramonium affecting some canopy characteristics. Australian Journal of Crop Science 4:684694.

Michael, P.W. 1983. Taxonomy and distribution of Echinochloa species with special reference to their occurrence as weeds of rice. p. 291-306. In Weed control in rice. International Rice Research Institute (IRRI), Laguna, Philippines.

Ni, H., K. Moody, R.P. Robles, E.C. Paller, and J.S. Lales. 2000. Oryza sativa (L.) plant traits conferring competitive ability against weeds. Weed Science 48:200-204.

Novak, M.G., L.G. Higley, C.A. Christiansses, and W.A. Rowling. 1993. Evaluating larval competition between Aedes albopictus and A. triseriatus (Diptera: Culcidae) through replacement series experiments. Environmental Entomology 22:311-318.

Oberg, A.L., L.J. Young., and L.G. Higley. 1996. A comparison of two measures of competition. Journal of Agricultural, Biological, and Environmental Statistics 4:393-403.

Radosevich, S.R. 1987. Methods to study interaction among crops and weed. Weed Technology 1:190-198.

SAS Institute. 2002. SAS System, Version 9.1. SAS Institute, Cary, North Carolina, USA 
Smith, R.J. Jr. 1988. Weed thresholds in southern U.S. rice, Oryza sativa. Weed Technology 2:232-241.

Stauber, L.G., R.J. Jr. Smith, and R.E. Talbert. 1991. Density and spatial interference of barnyardgrass (Echinochloa crus-galli) with rice (Oryza sativa). Weed Science 39:163-168.

Vangessel, M.J., and A.R. Karen. 1990. Redroot pigweed (Amaranthus retroflexus) and barnyardgrass (Echinochloa crusgalli) interference in potatoes (Solanum tuberosum). Weed Science 38:338-343.
Yabuno, T. 1966. Biosystematic study of the genus Echinochloa. Japanese Journal of Botany 19:277-323.

Yaghoubi, B., E. Zand, and A. Joharali. 2006. New species of Echinochloa a serious problem for Iran paddy. The $17^{\text {th }}$ Iranian Plant Pathology Protection Congress, Karaj, Iran. 29 August-2 September 2006. University of Tehran, Karaj, Iran.

Yamasue, Y. 2001. Strategy of Echinochloa oryzicola Vasing. for survival in flooded rice. Weed Biology and Management 1:28-36. 